\title{
Implementation of Learning Teaching Factory Clothes SMK N 3 Malang
}

\author{
Nur Cahyaningrum ${ }^{1}$, Agus Hery S.I ${ }^{2}$ \\ ${ }^{1,2}$ Pendidikan Kejuruan, Pascasarjana-Universitas Negeri Malang \\ "Corresponding author.E-mail: noercaning@gmail.com
}

\begin{abstract}
This research was conducted to evaluate the Teaching Factory learning in the boutique fashion skills program at SMK N 3 Malang. The research method used is a descriptive approach. The main subjects in this study were the teacher managing the Teaching Factory and the head of the Boutique Clothing expertise program at SMK N 3 Malang. Data collection using interviews, observation, and documentation. The data analysis technique used is descriptive analysis. The results in this study indicate that 1) The implementation of the Teaching Factory learning program carried out on the SMK N 3 Malang Boutique Clothing expertise program, overall looks good,2) The atmosphere, environment, and culture of the school support the Teaching Factory learning process 3) Support of competent human resources in the field of boutique clothing. While the inhibiting factor is the lack of appropriate facilities, so it is tricked by the division of groups so that learning runs effectively.
\end{abstract}

Keywords: implementation, learning, teaching factory, boutique clothing, vocational school

\section{INTRODUCTION}

The globalization era at the moment has many beneficial and detrimental impacts. The beneficial effect when the opportunity for cooperation with foreign countries is as wide open as possible. Another detrimental effect is when the inability to compete with foreign countries, due to weak Human Resources (HR) so that the consequences will harm the nation. The root of the weaknesses of Indonesian human resources can be seen through existing education. Vocational High School (SMK) is a formal educational institution that is expected to be able to make prospective workers suitable for the needs of the workforce. The learning process at SMK emphasizes more on the application of theories that have been given through practical activities. Vocational High School (SMK) is a form of government investment in formal vocational education which aims to prepare students to become skilled workforce by prioritizing special abilities, for that SMK is divided into various study program expertise. In the future, this process is expected to be able to produce high quality and highly competitive workforce.

The Directorate of Vocational Development has prioritized the development of vocational education systems that are oriented to improving truly professional graduates, have a work ethic, are disciplined and continue to uphold and are rooted in the nation's culture (Directorate of Vocational Development, 2009: 16). The policy is intended to raise the level of SMKs from merely supply-driven to demanddriven and market-driven by launching a re-engineering program aimed at increasing the role of SMKs as integrated vocational education and training centers. In its implementation, education in vocational schools is more emphasized on the learning approach by adopting managerial patterns in the industrial world which are integrated with a customized curriculum. This concept brings the mission of technology transfer from industry to SMK.

In addition to these policies, the education that is held must be able to anticipate the challenges of the globalization era. Based on the official news statistics No. 41/05 / Th. XXII, May 6, 2019. The total workforce in February 2019 was 136, 18 million people, up 2.24 million compared to February 2018. In line with the increase in the workforce, the Labor Force Participation Rate (TPAK) also increased by 0,12 percentage points. In the past year, unemployment decreased by 50 thousand people, in line with the TPT which fell to 5, 01 percent in February 2019. Judging from the level of education, TPT for Vocational High Schools (SMK) is still the highest among other education levels, amounting to 8, 63 percent.

In Indonesia, the application of the concept of teaching factory was introduced in SMKs in 2000 in a very simple form in the form of the development of production units that had been implemented in SMKs. Then the concept developed in 2005 into a model of industrial-based vocational development. There are three basic forms of industrial-based SMK development categories, namely: 1) Simple industrial-based SMK development; 2) Development of a developing industry-based SMK and; 3) Development of industry-based SMKs that develop in the form of factories as places of learning. Then later in early 2011 the development of SMKs with the third model, namely the development of industry-based SMKs that developed in the form of factories as places of learning, hereinafter known as teaching factories. 
According to the Directorate of PSMK (2016: 90), Teaching Factory is an industry-based learning concept (products and services) through the synergy of schools and industries to produce competent graduates by following market needs. The concept of industry-based learning means that each practice product produced is something that is useful and has economic value or marketability and is accepted by the market. The Synergy between schools and industry is a key element of success in Teaching Factory, where Teaching Factory will be a means of connecting for cooperation between schools and industry. Continued school-industry interaction will encourage continuous improvement in terms of technology (technology transfer), curriculum and industry culture so that it will have an impact on graduates who are competent and have abilities that are required by the industry, which is aware of quality and efficiency as always applied in industrial activities.

Many educational institutions are trying to bring educational practices close to the industry. So that Teaching Factory has become a new approach to vocational education with the aim of (1) modernizing the teaching process by bringing industry practices closer; (2) leveraging industry knowledge through new knowledge; (3) supports the transition from manual to automatic work and reduces the gap between industrial resources ( workers and capital) and industry knowledge (information); (4) increase and maintain the growth of industrial wealth.

According to Hidayat (2011), this teaching factory model aims to improve the productive competence of vocational students by using six steps from one cycle of this model, namely accepting order givers, analyzing orders, expressing readiness to work on orders, working on orders, doing quality control, and handling orders. The implementation of these steps will have an effective impact on increasing the productive competence of vocational students. Besides, it has its impact on increasing the ability to work readiness of students when they have graduated to enter the industrial world. The application of a Teaching Factory that is based on the learning process as in the industrial environment will have a good effect because the size of 3 achievements/work results in the industrial environment is measured by accepted or rejected. Risk of failure means loss of money and damaged reputation, strict use of time, failure and delay are considered losses. The work environment allows everyone to improve the quality and productivity of their work. These conditions have contributed to the formation of a high work ethic. The implementation of teaching factories is important in learning in vocational schools because according to the results of research Teng et al. (2001), by using teaching factory technical knowledge, group skills and real-world work experience students can be improved.

At this time SMK N 3 Malang has implemented a teaching factory learning program, which is making AREMA uniforms in collaboration with PT. Seven Col. The teaching factory in SMK N 3 Malang on the Boutique Clothing expertise program began in 2017 and began working with PT.Seven Col.
The formulation of the problem in this research are as follows:

1. How Implementing Teaching Factory at SMK Negeri 3 Malang?

2. Are there any obstacles encountered in the implementation of the teaching factory in SMK N 3 Malang?

3. What efforts have been made to deal with obstacles that have arisen in the process of implementing Teaching Factory?

\section{METHOD}

The form of research used in this study is qualitative research. "Qualitative research is a particular tradition in social science that fundamentally depends on observing humans and their region and relating to these people in their language and terminology" (Moleong, 2001: 3). The method used in this research is descriptive research. The Research conducted seeks to describe the state of objects of research regarding the implementation of teaching factories in SMK N 3 Malang based on the fact on the field.

This research was conducted at SMK N 3 Malang with initial observations in July 2019. The research subjects in this study were the teacher and head of the SMK N 3 Malang Boutique Clothing Boutique expertise program.

Data collection techniques in this study used interviews, observation, and documentation. The data obtained were analyzed using descriptive data analysis. Research data obtained later described.

\section{RESULTS AND CONCLUSION \\ Teaching Factory Learning}

SMK N 3 Malang is one of the vocational schools which is a favorite of the people in Malang. SMK N 3 Malang is located on J1. Surabaya No.1, Gading Kasri, Kec. Klojen, Malang City. Founded in 1953 which was once SKP (equivalent to SLTP / SMP), then became SMKK in 1979. SMK N 3 Malang starts implementing Teaching Factory learning in 2017. Teaching Factory learning which is carried out at SMK N 3 Malang is expected to be able to produce SMK graduates with competent boutique fashion expertise programs that can meet the needs of the industrial world.

The definition of learning is mentioned by Heinich (1996: 6) as follows: "Learning is the development of knowledge, skills, or attitudes as an individual interacts with information and the environment". The learning environment includes the physical facilities, the psychological atmosphere, instructional technology, media, and methods. "In this definition learning is defined as the interaction between a person with information and the environment. The learning environment includes physical facilities, psychological atmosphere, learning technology, media, and methodology.

According to G. Chryssolourisa, D. Mavrikiosa and, L. Rentzosa (2016) states that the use of a teaching factory is for two-way communication between academics and 
industry. The teaching factory paradigm provides a reallife environment for students and researchers to develop their skills and understand the challenges faced in everyday industrial practice. So the benefits of SMK N 3 Malang in collaboration with industrial companies can put students in learning following the industrial world.

Production-based learning in the old paradigm only prioritizes the quality of products both goods or services, but the results of the production are not used or marketed to produce value in teaching and learning. Productionbased learning in the new paradigm can produce goods that can be sold or used by the community, schools, and consumers. Teaching factory learning is thus part of production-based learning in the new paradigm. Teaching factory learning is more directed to the process of managing management in classrooms and practical spaces based on procedures and working standards in the industrial world. A teaching factory also means learning expertise or skills that are designed and implemented based on actual work procedures and standards to produce goods or services following the market or consumer demands. The teaching factory learning process is thus approaching the real atmosphere.

The Boutique Clothing expertise program at SMK N 3 Malang has a teaching factory product, namely the manufacture of AREMA uniforms in collaboration with PT. Seven Col. With TEFA learning, it is proven that it can improve student competence, hard work ethics and entrepreneurial spirit of students. Before carrying out the previous collaboration, an agreement was made regarding the product to be carried out the required grace period, costs in the production process, and the agreed product quality. The agreement made between the teaching factory of fashion design SMK N 3 Malang with PT. Seven Col is not binding. There is also Three Can, which is the result of the practice of all students in fashion. Depending on the level of difficulty in making products is what distinguishes the work of class X, XI, and XII. For example, a dress that requires a lot of sequins is a class XII student work, while the product is as simple as apron and culinary hat tilled $\mathrm{X}$ class.

\section{Teaching Factory Implementation in SMK N 3 Malang in Terms of HR Aspects}

Human resources (HR) in schools include educators, education staff, and also students (students). Educators/teachers in teaching factory teaching are resources that have an important role. Based on Law No.20 2003 Article 39 Paragraph (2) it is stated that educators are professionals who are tasked with planning and implementing the learning process, assessing learning outcomes, conducting mentoring and training, and conducting research and community service, especially for educators at tertiary institutions.

The results of the research implementation of teaching factory at SMK N 3 Malang in the Boutique Clothing Expertise Program with a human resource spec that the selection of educators is not only considered from academic factors but also industry experience. The attitude and knowledge that was formed since they were apprenticed in the industry gave their advantages in the teaching factory. Because they are familiar with the working atmosphere in the industry. Considering some of the experiences that teachers have tended to improve and the products developed are also new products, the instructor must adjust to the implementation of teaching factories in schools. For teachers who do not yet feel the state of the industry, the school overcomes these problems by holding an industrial visit where teachers can learn about the situation and atmosphere in the industry. Spatial planning, lighting, clothing, attitudes, and work regulations can be directly observed during industry visits. Educators at SMK N 3 Malang teacher competencies needed in the implementation of teaching and learning factory teaching, namely the professional competence of teachers and the real competence of Boutique Clothing skills. This means that teachers are not only able to sew, design, cut designs, theoretically inflate but also practice.

\section{Teaching Factory Implementation in SMK N 3 Malang in Terms of Aspects of Partnership}

The cooperative relationship between SMKs and industry in teaching factory teaching patterns will have a positive impact on building a systematic and planned partnership mechanism based on a win-win solution bargaining position. The application of teaching factory teaching patterns is an interface of the world of vocational education with the industrial world, so there are a check and balance of the educational process at vocational schools to maintain and maintain harmony ( link and match ) with the needs of the job market.

Learning through teaching factory aims to foster character and work ethic (discipline, responsibility, honesty, cooperation, leadership, etc.) needed by DU / DI and improve the quality of learning outcomes rather than just providing competency ( competency-based training ) towards learning that equips the ability to produce goods / services ( production-based training ).

SMK N 3 Malang in collaboration with PT. Seven Col and other DUDI start from 2017. Cooperation School and DUDI organize education and training for teachers and students and provide opportunities for the recruitment of workers. Also, once a year a meeting is held between the school and DUDI which contains a series of evaluation activities on the curriculum, competency testing and discussion of obstacles that need to be overcome and resolved.

\section{The Teaching Factory Implementation in SMK N 3 Malang is Evaluated From the Aspect of Infrastructure Facilities}

The simple concept of teaching factory is the development of a dual system of education, namely Competence-Based Training (CBT), and Production Based Education and Training (PBET) which are implemented by SMKs. This is adjusted to the statement made by Triatmoko (2009: 35), that SMKs are still having difficulty implementing production-based education. Therefore the term teaching 
factory was raised which requires schools to have a place for students to carry out practical learning that is designed so that it resembles the work environment. Characteristics of schools that run teaching factories, namely facilities and infrastructure owned in a school $60-70 \%$ are used for 8 production activities, business activities carried out only business and production operations, and the income owned is different from the characteristics of schools that carry out education production-based where $90 \%$ of facilities and infrastructure owned are used for production activities, business processes carried out complete with business support and the revenue generated is able to cover operational financing as well as investment (Triatmoko, 2009: 71).

Some indicators used to assess the building/teaching factory space in this study include the status of the building, the location of the building against other rooms, the area of the building, the use of buildings and the condition of the building. Meanwhile, to assess the production unit equipment. used several indicators consisting of production equipment, electricity networks, student work tables/chairs, teacher demonstration tables, blackboards, markers, erasers, cabinets/shelves where equipment, work guidelines/order, information boards, and fire extinguishers.

Furthermore, based on the results of observations at SMK N 3 Malang that have been carried out on the availability of teaching factory equipment shows that most of the teaching factory equipment is already available and can be used in learning activities in schools. However, there are still things that are felt less by teachers and students, namely sewing machines, overlock machines, and irons that should be per participant of 1 machine's learners but have not yet fulfilled. Furthermore, for other equipment generally available and complete, such as an adequate electricity network, work desks for students, teacher demonstration tables, blackboards, markers and erasers available, cabinets/shelves for storing equipment, work guidelines/rules, boards information is also available

SMK N 3 Malang, in the boutique fashion expertise program, there are no special officers to handle the maintenance and inventory of infrastructure for every boutique fashion study. All treatments are carried out by the teacher and the teaching factory team. When there is damage, the school will call a special technician to repair damaged equipment when the teaching factory team is unable to repair it.

The process of inventorying facilities at SMK N 3 Malang in teaching factory learning is carried out by productive teachers in boutique fashion. Inventory of boutique fashion production facilities aims to make TeFa's team and majors know about the procurement of goods. Renewal or repair of Boutique Fashion infrastructure under the responsibility of the Teaching factory team. The optional process for the procurement of infrastructure facilities involves the Head of the Boutique Clothing Expertise Program, Ms. Ana Isro Illiani, and the Teaching factory team will hold a meeting to determine the infrastructure that must be updated and repaired.
At the end of the learning year, the teaching factory team will evaluate the feasibility of the boutique fashion learning infrastructure by the teaching factory team. This is done to make improvements or purchase infrastructure in the new learning year. So that the existing infrastructure can advance the quality of teaching factory learning and be able to improve the competency of student expertise. An evaluation is also held after each study program leader submits the procurement of goods and reports the inventory of goods to the teaching factory team.

The results of the above study are in accordance with the research of Siswandi and Sukoco (2015) showing that the teaching factory model that was developed was in accordance with the required criteria, namely: (1) the availability of space as a place to practice; (2) There is a production unit as a place for implementing the process; (3) available facilities and supporting infrastructure such as tools, keys, and machinery; (4) has utilized local environmental conditions in the process of learning practices.

Based on the results of the evaluation it can be concluded that in general the aspects of facilities and infrastructure are adequate, although there are deficiencies and damage to the facilities that need to be repaired.

\section{Teaching Factory Implementation in SMK N 3 Malang in Terms of Product Aspects}

The concept of teaching factory learning is an effort carried out by vocational schools in improving the quality and achievement of graduation. Through teaching factory learning activities, it is expected that entrepreneurship values emerge in students' souls, such as honesty, creative, innovative and others. The entrepreneurial spirit can be seen from the activities carried out by students when marketing the products produced both goods and services, students can show goods in detail to consumers, students can create and improve products, even able to design a product for the better.

No matter how good a product is but not needed by consumers, it can be detrimental to producers. Likewise, the products needed by consumers, would be but the quality is not good, also not be used by consumers. Products produced in teaching factories must be of high quality. The products and services produced must be by industry standards.

The results of research in SMK N 3 Malang that students are skilled at producing fashion products that can compete with other professional products. Where student products have the same quality as other products produced by garment companies and other boutiques. Good quality student products in addition to being supported by teachers who have good competence and infrastructure that supports student productivity and partnerships that always help schools in providing training and education to students. The quality of the results of students' fashion products can be relied on with those who have good indications of stitching and the selection of quality materials. Besides the indication of the reliability of the products produced by students, another interesting thing is 
that the creativity and innovation of students in the practice of fashion has a high potential for selling power. Consumers are always waiting for the results of the production of clothing made by students, this is because students can absorb the imagination of fashion variations. The results of student clothing are also well received by the community because it is unique. The products that produce the most so that they can be used in the learning process of Fashion Clothing are shirts, paskibraka uniforms, choir uniforms, school goody bags, borders and screen printing (from industry) and school uniforms.

The above findings are following the Book published by the Directorate of Vocational High School Development, which explains the Teaching Factory Governance (2017) that products / services for internal needs, market acceptance, delivery, quality, quality control, and product innovation/diversification. The products of the Boutique Boutique competency product meet the internal needs of the school in the form of school uniforms worn by students of SMK N 3 Malang.

Products of SMK N 3 Malang Boutique Clothing competence is always awaited by the community and is always accepted by consumers because it is unique and creative. Students also always innovate and imagine the fashion designs that are made. The quality of their products can compete with professional products from garment and boutique companies. Teachers always control the quality of clothing production by students of the Boutique Clothing competency at SMK N 3 Malang.

The results of research on Boutique Clothing products in SMK N 3 Malang by research owned by Hidayat (2011) to improve the productive competence of vocational students. Six steps from one cycle of this model, namely accepting the order giver, analyzing the order, expressing readiness to work on the order, working on the order, doing quality control, and handing over the order. Before the model cycle is implemented, students and teachers do an agreement to create an industrial climate in the school, do communication exercises, and practice analyzing orders.

According to Fuandi (2016) shows that a product needs to upgrade the packaging design of products that are more attractive and sell. Also, it is necessary to actively participate in various events, such as exhibitions, competitions, and introduction to the media so that the product can be known to the public. SMK N 3 Malang itself seen from the popularity of the product among the people the process above has been fulfilled.

\section{Constraints in the Implementation of Teaching Factory and Efforts to Overcome It}

The obstacle faced in the implementation of Teaching Factory in SMK N 3 Malang is the lack of practical tools that fit the needs of students. Ideally, each student practices using 1 machine per person, including sewing machines, overhaul, and iron, but because of the lack of these tools, the solution is the division of labor, between students who sew and students who cut material. So the teaching factory learning process continues to run well.

\section{CONCLUSIONS}

- Teaching factory learning at SMK N 3 Malang began in 2017. In its implementation in collaboration with PT. Sevencol for making AREMA uniforms

- The implementation of Teaching factory in SMK N 3 Malang in terms of HR, The results of research on the implementation of teaching factory in SMK N 3 Malang in the Boutique Clothing Expertise Program with aspects of human resources that the selection of educators is not only considered from academic factors but also industry experience. The attitude and knowledge that was formed since they were apprenticed in the industry gave their advantages in the teaching factory. Because they are familiar with the working atmosphere in the industry. Considering some of the experiences that teachers have tended to improve and the products developed are also new products, the instructor must adjust to the implementation of teaching factory in schools

- Teaching factory implementation in SMK N 3 Malang in terms of the Partnership aspect, SMK N 3 Malang in collaboration with PT. Seven Col and other DUDI start from 2017. Cooperation School and DUDI organize education and training for teachers and students and provide opportunities for the recruitment of workers. Also, once a year there is a meeting between the school and DUDI which contains a series of evaluation activities on the curriculum, competency testing and discussion of obstacles that need to be overcome and resolved.

- Teaching factory implementation in SMK N 3 Malang in terms of Infrastructure Facilities, at SMK N 3 Malang that has been conducted on the availability of teaching factory equipment shows that most teaching factory equipment is already available and can be used in learning activities in schools. However, there are still things that are felt less by teachers and students, namely sewing machines, overlock machines, and irons that should be per participant of 1 machine's learners but have not yet fulfilled.

The process of inventorying facilities at SMK N 3 Malang in teaching factory learning is done by productive teachers in boutique fashion. Inventory of boutique fashion production facilities aims to make TeFa's team and majors know about the procurement of goods. Renewal or repair of Boutique Fashion infrastructure under the responsibility of the Teaching factory team. The optional process for the procurement of infrastructure facilities involves the Head of the Boutique Clothing Expertise Program, Ms. Ana Isro Illiani, and the Teaching factory team will hold a meeting to determine the infrastructure that must be updated and repaired.

- Teaching factory implementation in SMK N 3 Malang in terms of product aspects, the results of research in SMK N 3 Malang that students are skilled in producing fashion products that can compete with other professional products. Where student products have the same quality as other products produced by garment companies and other boutiques. Good quality student products in addition to being supported by teachers who have good competence and infrastructure that supports student productivity and 
partnerships that always help schools in providing training and education to students. The products that produce the most so that they can be used in the learning process of Boutique Clothing are shirts, paskibraka uniforms, choir uniforms, school goody bags, borders and screen printing (from industry) and school uniforms.

- Constraints in the Implementation of Teaching Factory and Efforts to Overcome It, The obstacle faced in the implementation of Teaching Factory in SMK N 3 Malang is the lack of practical tools that fit the needs of students. Ideally, each student practices using 1 machine per person, including sewing machines, overhaul, and iron, but because of the lack of these tools, the solution is the division of labor, between students who sew and students who cut material. So the teaching factory learning process continues to run well.

\section{REFERENCES}

[1] BPS , (2019). National Open Unemployment Data, Jakarta: Central Statistics Agency

[2] Directorate of PSMK. (2009 ). Roadmap for developing SMK 2010-2014. Jakarta: Ministry of National Education.

[3] Fuandi, Afnan. 2016. Evaluation of Teaching factory Learning Program in the Middle School of Fisheries Business. PERSPECTIVE Education Science Vol. 30 No. October 2, 2016.

[4] G. Chryssolourisa, et al. 2016. The Teaching Factory: A Manufacturing Education Paradigm. Procedia CIRP 57 (2016) 44 - 48.

[5] Heinich, Molenda, R . M., Russel, JD , \& Smaldino, SE (1996). Instructional technology and media for learning eight editions. New Jersey: Pearson Merrill Prentice Hall Inc.

[6] Hidayat, Dadang. 2011. Teaching Factory Learning Model To Increase Student Competence in Productive Subjects. Journal of Educational Sciences. 17 (4): 270-278.

[7] Moloeng J. Lexy. (2000). Methodology Qualitative Research. Bandung: PT Remaja Rosdakarya.

[8] Siswandi, Galfri \& Sukoco. 2015. Development of Teaching Factory Model in Vocational High School Automotive Workshop at Karsa Mulya Palangka Raya. Journal of Technology and Vocational Education, Volume 22, Number 4.

[9] Teng, SG, Schhreiner, S., Nelson, JB (2001). Teaching in the Factory: Connecting Industry to Engineering Education. Industry \& Higher Education, 15 (5), 353-359

[10] Triatmoko. (2009). The ATMI Story, a rainbow of excellence. Surakarta: Atmipress Law No.20 2003 Article 39 Paragraph (2) 